likely to be infected than exclusively homosexual men, and our data suggest that two distinct populations may exist. In general the prevalence of HIV infection in homosexual men clearly exaggerates the risk of heterosexual spread from this source.

The part played by the information campaign funded by the government in bringing about modifications in homosexual lifestyle seems to have been small. The most substantial changes had occurred before the campaign started, and the reduced trend towards safer practices in the most recent cohort may be attributable to the government's reluctance to target the homosexual community in its subsequent publicity. Although selection of partners and use of condoms may militate against transmission of HIV, at risk behaviour is clearly still taking place, and more effort is required to reduce it to the best attainable minimum.

We thank Dr Berge Azadian for handling the serum samples, Dr Jonathan Coleman for data on hepatitis B, Marion Hudson for preparing the graphs, Helenlouise Taylor for data handling, and Sarah O'Connor for typing the manuscript.

I Goedert JJ, Sarngadharan MG, Biggar RT, et al. Determinants of retrovirus (HTLV-III) antibody and immunodeficiency conditions in homosexual men. Lancet 1984;ii:711-6.
2 Evans BA, Dawson SG, McLean KA, et al. Sexual lifestyle and clinical findings related to HTLV-III/LAV status in homosexual men. Genitourin Med 1986;62:384-9.

3 Winkelstein W, Liman DM, Padian N, et al. Sexual practices and risk of infection by the human immunodeficiency virus. The San Francisco men's infection by the human immunodeficienc

4 Kingsley LA, Detels R, Kaslow R, ct al. Risk factors for seroconversion to human immunodeficiency virus among male homosexuals. Results from the multicentre AIDS cohort study. Lancet 1987;ii:345-9.

5 Department of Health and Social Security. AIDS: don't die of ignorance. London: DHSS, 1987

6 Mortimer PP, Parry JV, Mortimer JY. Which anti-HTLV III/LAV assays for screening and confirmatory testing? Lancet 1985; ;i: $873-8$.

7 Dixon WJ, ed. B.MIDP statistical software. Berkelev: University of California, 1983.

8 Hill AB. A short textbook of medical statistics. London: Hodder and Stoughton, 1977

9 Goedert JJ. Sounding board: what is safe sex? N Engl f Med 1987:316: $1339+42$.

10 Remafedi G. Homosexual vouth. A challenge to contemporary society. f AMA $_{1}$ 1987;258:222-5

11 Niedecken N, Lutz G, Bauer R, Krevsel HW. Langerhans cell as primary target and vehicle for transmission of HIV. Lancet 1987;ii:519-20.

12 Nelson JA, Wilev CA, Reynolds-Kohler C, Reese CE, Margaretten W', Lewy $J A$. Human immunodeficiency virus detected in bowel epithelium from patients with gastrointestinal symptoms. L Lancet 1988;i:259-62.

13 Eales L-J, Nye KE, Parkin JM, et al. Association of different allelic forms of group specific component with susceptibility to and clinical manifestation of human immunodeficiency virus infection. Lancet 1987;i:999-1002.

14 Eales L-J, Nye KE, Pinching AJ. Group specific component and AIDS erroneous data. Lancet 1988; ; 936 .

15 Weber JN, McCreaner A, Berrie E, et al. Factors affecting seropositivity to human T cell lymphocytic virus type III (HTLV-III) or lymphadenopath associated virus $(\mathrm{LAV})$ and progression of disease in sexual partners of patients with AIDS. Genitourin .Med 1986;62:177-80.

Accepted 17 November 1988

\title{
Changes in sexual behaviour and the fall in incidence of HIV infection among homosexual men
}

\author{
Godfried J P van Griensven, Ernest M M de Vroome, Jaap Goudsmit, Roel A Coutinho
}

Department of Infectious Diseases, Municipal Health Service, PO Box 20244, $1000 \mathrm{HE}$ Amsterdam, The Netherlands Godfried J P van Griensven, MS, methodologist Roel A Coutinho, MD, microbiologist

\section{Department of Studies on Homosexuality, State University of Utrecht, Utrecht, The Netherlands Ernest M M de Vroome, MS, psychologist}

Department of Virology, University of Amsterdam, Amsterdam, The Netherlands

Jaap Goudsmit, MD, virologist

Correspondence and requests for reprints to: $\mathrm{Dr}$ van Griensven.

\begin{abstract}
To investigate the epidemiology and normal course of infection with HIV the prevalence and incidence of the infection were studied among two cohorts of homosexual men in Amsterdam in 1980-7. The cumulative incidence of infection increased from a weighted $2 \cdot 2 \%$ in 1980 to $39.0 \%$ in 1987 . The estimated yearly incidence of HIV was $3.0 \%$ in 1981 , rose to $8.8 \%$ in 1984 , and fell gradually to $0 \%$ in 1987 . During the study the sexual behaviour of the cohorts was examined. The number of men with whom anopenetrative intercourse was practised fell from a mean of 10.6 to 1.4 for those positive for HIV antibody, whereas the number with whom anoreceptive intercourse was practised fell from a mean of $3 \cdot 7$ to 0.5 for those negative for the antibody. In addition, there was a reduction in the number of cases of hepatitis $B$ and syphilis among men in general.
\end{abstract}

The decline in infection with HIV was assumed to be linked to changes in sexual behaviour. Such changes practised early in the course of the epidemic probably had a strong effect on the number of cases of AIDS among homosexual men in Amsterdam.

\section{Introduction}

In 1982 the first case of AIDS in The Netherlands was diagnosed in a homosexual man. ${ }^{\prime}$ By April 1988 , 487 cases had been reported, of which 413 were in homosexual men. ${ }^{2}$ To investigate the epidemiology and the natural course of infection with HIV a cohort study was started in October 1984 among 746 homosexual men in Amsterdam. Earlier epidemiological, clinical, and immunological results of this study have been reported. ${ }^{3-6}$ This paper reports the cumulative incidence of HIV infection in this cohort in relation to changes in sexual behaviour. In addition the probable course of the spread of HIV in this cohort was assessed by reconstructing the epidemiological curve over the past seven years. This reconstruction was based on the retrospectively determined prevalence and incidence of HIV infection in a cohort of homosexual men who participated in a trial of hepatitis B vaccine in $1980-2 .^{7 *}$

\section{Subjects and methods}

STUDY POPULATION

Two cohorts were studied. The first comprised 746 homosexual men who were participating in a prospective study of HIV infection and AIDS that started in October 1984 (the AIDS cohort study)..$^{3-6}$ The second comprised 685 men who participated in a placebo controlled trial of the efficacy of a heat inactivated hepatitis B vaccine from November 1980 to November $1982 .{ }^{78}$ In both cohorts participants were healthy male homosexual volunteers, most of whom lived in and around Amsterdam. Participants in the hepatitis $B$ vaccine trial were negative for markers of hepatitis B infection. The design of these studies, as well as demographic and other characteristics of the participants, have been described previously. ${ }^{3.8}$

\section{CONDUCT OF THE STUDY}

Participants in the AIDS cohort study were enrolled from October 1984 to May 1985 and were seen every three months at the Municipal Health Service of Amsterdam. This study covers data collected until October 1987. When they entered the study subjects were physically examined and their medical history was taken. Every three months blood samples were collected for virological and immunological tests. Presence of antibody to HIV was established with two enzyme linked immunosorbent assays (ELISA; Organon, Oss, The Netherlands, and Abbott, north Chicago, United States) and confirmed by immuno- 
blotting. ${ }^{\circ}$ All subjects were informed of their results two weeks after they entered the study. Among men negative for HIV antibody the procedure was repeated every three months. Every six months subjects completed a self administered questionnaire on their sexual behaviour in the preceding six months. During the study 97 men negative for HIV antibody failed to return for follow up. Most of them had said that they did not want to know the result of their test for HIV antibody. Comparison of demographic background data on these men with those on the men who remained in the study did not show any differences.

Subjects in the trial of hepatitis B vaccine entered the study from November 1980 to December 1981. Follow up continued until December 1982. At entry participants were questioned about their medical history and sexual lifestyle. Blood samples were taken during each of the first five months of the study and every three months thereafter. The first and last blood samples were retrospectively investigated for the presence of HIV antibodies as described above. If antibodies were found in the last sample all intervening samples were tested to determine the date on which antibodies were first evident. This retrospective analysis of stored blood samples was incomplete for 112 susceptible men: 30 subjects were lost because of lack of motivation or because they moved and no last blood sample was collected from 82 subjects because the trial was finished.

\section{STATISTICAL METHODS}

The incidence of seroconversion for each six month interval-that is, for each interval the number of subjects who became positive for HIV antibody divided by (the number of subjects entering interval minus $0.5 \times$ number of subjects withdrawing during the interval) - was calculated with life tables according to the actuarial method" and expressed as a percentage. The reconstruction of the epidemiological curve in the AIDS cohort was based on data from HIV serological testing in both cohorts and on the estimation of the cumulative incidence of HIV infection in 1982-4. The prevalence of HIV antibody among men negative for hepatitis B virus markers in the AIDS cohort was $11 \cdot 7 \%(14 / 120)$ at entry. In the total study population (excluding those vaccinated against hepatitis B) the prevalence was $35 \cdot 3 \%$ (220/624). From these figures we concluded that men negative for hepatitis B virus antibody were at lower risk of becoming infected with HIV. Data on the prevalence and incidence of HIV infection in the cohort were therefore weighted for this difference. The weight factor was taken as the ratio of the proportion of men positive for HIV antibody among all the men entering the AIDS cohort study to the proportion of the men positive for HIV antibody among those negative for hepatitis $B$ virus antibody on entering the study. This ratio was $35 \cdot 3 / 11 \cdot 7=3 \cdot 01$. A polynomial was fitted in the weighted values for $1980-2$ and the observed values

FIG 1-Cumulative incidence of HIV infection among 746 homosexual men participating in AIDS cohor study in Amsterdam, October 1984 to October 1987

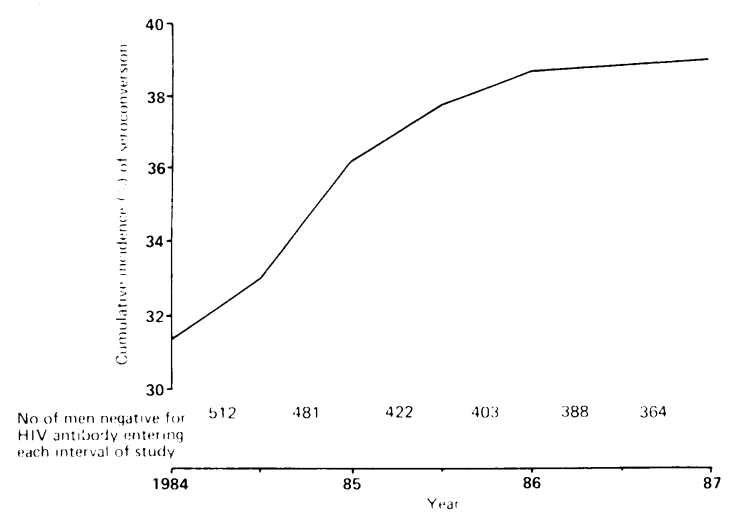

for 1984-7. ${ }^{10}$ The regression equation was used to estimate the cumulative incidence for 1982-4, for which no actual data existed. A cubic polynomial produced an excellent fit $\left(R^{2}=0.973\right)$. Because there were no data to validate the estimated curve this procedure was rather speculative, and no measures of statistical uncertainty are therefore presented.

\section{Results}

CHARACTERISTICS OF THE TWO COHORTS

At entry the men in the AIDS cohort were older, had been homosexually active longer, and had had a higher level of risky sexual activity than the men participating in the vaccine trial (table). These differences were to be expected because participants in the vaccine trial were negative for hepatitis B virus markers.

Characteristics of two cohorts of homosexual men in Amsterdam at entry into study, between November 1980 and December 1981 and October 1984 and May 1985 respectively

\begin{tabular}{lcc}
\hline & $\begin{array}{c}\text { Hepatitis B } \\
\text { vaccine trial } \\
\text { cohort } \\
(\mathbf{n}=685)\end{array}$ & $\begin{array}{c}\text { AIDS cohort } \\
(\mathbf{n}=746)\end{array}$ \\
\hline Mean (SD) age (years) & $31(7)$ & $35(7)$ \\
Mean (SD) No of years of homosexual activity & $11(7)$ & $17(8)$ \\
No (\%) who had had >10 sexual partners in past & $240(35)$ & $389(52)$ \\
six months & $507(74)$ & $643(86)$ \\
No (\%) who practised anal sex & & $501(67)^{\star}$ \\
No (\%) who had hepatitis B virus markers & &
\end{tabular}

^Excluding men vaccinated against hepatitis $B$.

PREVALENCE AND INCIDENCE OF HIV INFECTION IN THE AIDS COHORT STUDY

When the participants entered the AIDS cohort study (October 1984 to May 1985) 234 (31.4\%) out of 746 had antibodies to HIV. During follow up until October 1987, 52 men became positive for antibody to HIV, resulting in an incidence of $11 \cdot 2 \%$. The slope of the curve of the cumulative incidence of $\mathrm{HIV}$ infection (fig 1) shows that most men became positive for antibody before the end of 1986, after which the curve started to level off. In October 1987 the cumulative incidence of HIV infection in the cohort was $39 \%$.

CHANGE IN SEXUAL BEHAVIOUR AND DECLINE IN INCIDENCE OF HIV INFECTION IN AIDS COHORT STUDY

The relation between changes in sexual behaviour of the cohort and the decline in transmission of HIV was examined by evaluating the decrease in the number of partners with whom anopenetrative and anoreceptive intercourse occurred. To evaluate the risk of becoming infected with HIV the mean number of partners with whom men negative for HIV antibody practised anoreceptive intercourse was studied, and the risk of disseminating HIV was evaluated by studying the mean number of partners with whom men positive for HIV antibody practised penetrative intercourse. Both groups reported a decrease in these practices (fig 2), primarily during the first 12 months of the study, men positive for the antibody showing more change than those negative for it (a reduction from a mean of 10.6 partners during the past six months to 2.9 partners among those positive for the antibody versus reduction from $3 \cdot 7$ to $1 \cdot 4$ ). During the remaining 24 months a slow decrease was seen, which resulted in an average number of 1.4 partners among those positive for antibody and 0.5 partners among those negative at the end of the study. The absolute number of partners with whom condoms were used while the men practised these activities remained more or less stable during the total study: an average of 1.0 among those positive for antibody and 0.5 among those negative. A comparison of figure 2 and figure 1 shows that the levelling off of 
FIG 2 - Mean number of partners with whom anogenital intercourse practised amon 746 homosexual men 512 negative for HIV antibody, 234 positive) participating in AIDS cohort study in

Amsterdam, October 1984 to October 1987

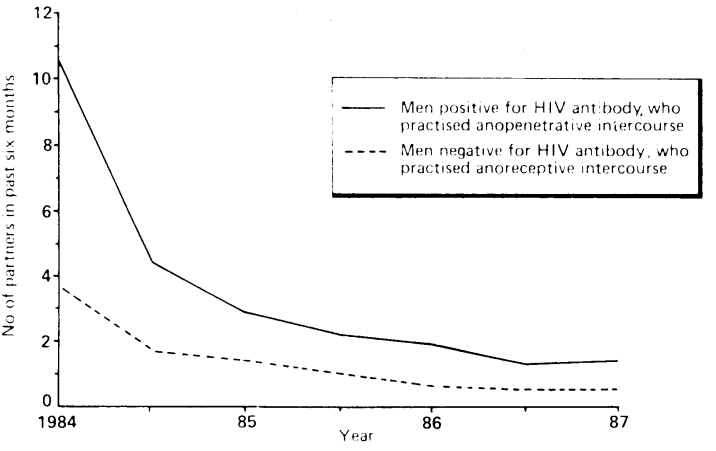

the rate of infection coincides with an approximate mean of zero partners with whom those negative for antibody perform anoreceptive intercourse without using condoms.

PREVALENCE AND INCIDENCE OF HIV INFECTION IN THE HEPATITIS B VACCINE COHORT

On entry into the trial of hepatitis $B$ vaccine from November 1980 to December 1981 , five $(0 \cdot 7 \%)$ out of 685 participants were positive for HIV antibody. During follow up 15 men became positive for antibody (three in 1981 and 12 in 1982), an incidence of 3\%. The trend in the observed cumulative incidence (fig 3) shows that most of the men who became positive did so in the second half of the study. When the prevalence
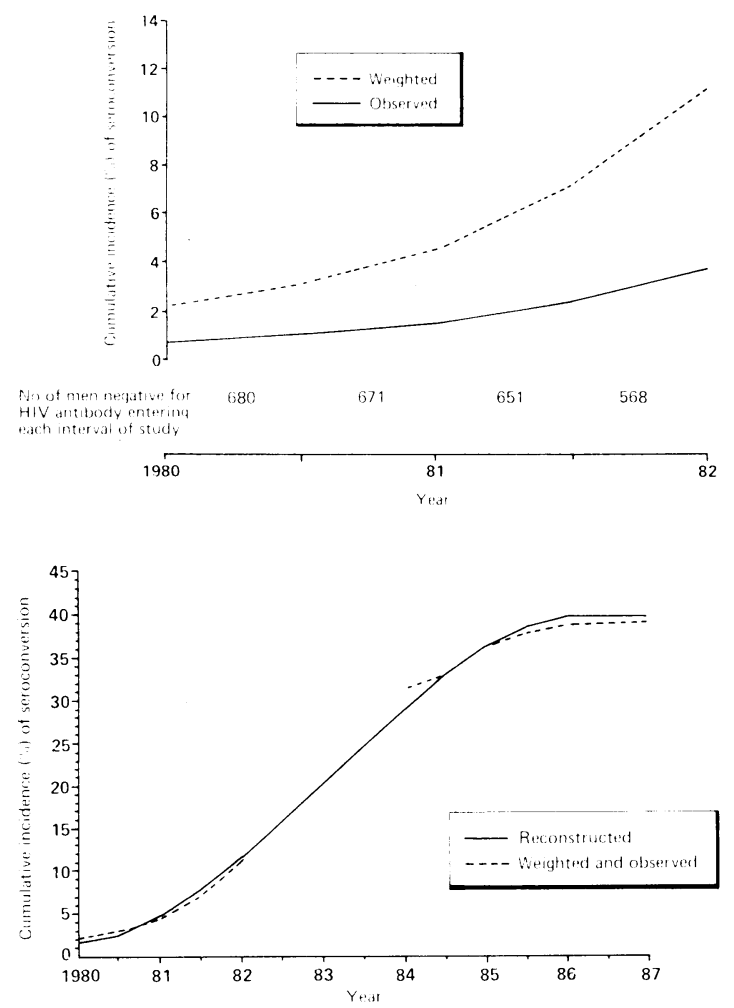
cumulative incidence of HIV infection among two cohorts of homosexual men in Amsterdam, November 1980 to October 1987 cumulative incidences of HIV infection among homosexual men participating in hepatitis $B$ vaccine cohort study in Amsterdam, November 1980 to December 1982

IG 5-Reconstructed yearl incidence of HIV infection among two cohorts of homosexual men in Amsterdam, November 1980 to October 1987 and incidence were weighted for the selection of men negative for hepatitis B antibody $2 \cdot 2 \%$ of the participants were positive for HIV antibody at entry and $9 \cdot 1 \%$ became positive during follow up. At the end of 1982 the weighted cumulative incidence was $11 \cdot 1 \%$.

\section{RECONSTRUCTION OF THE SPREAD OF HIV, 1980-7}

The estimates of the cumulative incidence of HIV infection in the unobserved period, 1982-4, were interpolated by a regression model. Figure 4 presents the reconstruction of the curve for the total period, 1980-7. According to this reconstruction, the cumulative incidence in the unobserved period rose from $15.8 \%$ in mid- 1983 to $20.3 \%$ in the beginning of 1984 and to $24.8 \%$ in mid-1984. The curve shows a steady progressive increase in the incidence of HIV infection in 1980-5 and an inflection in 1986-7. The yearly incidence based on this reconstruction (fig 5) shows a sharp increase from $3 \%$ in 1981 to $8.7 \%$ in 1983 , a plateau of $8.8 \%$ in $1983-4$, and a decline to $7 \%$ in 1985 , $3.5 \%$ in 1986 , and $0 \%$ in 1987 . Probably this is the course which the spread of HIV in the AIDS cohort ran.

\section{Discussion}

This report presents a reconstruction of the epidemiological curve of the spread of HIV among the homesexual men participating in the AIDS cohort study and its relation with changing patterns of sexual behaviour. The reconstructed rapid increase in the number of men positive for HIV antibody at the beginning of the epidemic is a classic example of the spread of a sexually transmitted disease. The rate at which such spread occurs depends on the number of partners, type of sexual contact, infectivity of the agent, and number of infectious people in the population. More than a third of the men who entered the AIDS cohort study from October 1984 to May 1985 were infected with HIV. These men reported a mean of more than 279 different sexual partners during the past five years and a mean of 24 partners during the past six months. In addition, they reported a mean of more than 10 sexual partners with whom they had practised anoreceptive intercourse during the six months preceding entry. ${ }^{3}$ This behaviour may account for the increase in the proportion of men positive for HIV antibody from the weighted $11 \%$ in 1982 to the observed 31\% from October 1984 to May 1985. The decline in transmission of HIV in the AIDS cohort from 1985 onwards was probably a result of the decrease in sexual activity in the studied population and more specifically the decrease in the number of partners with whom anogenital intercourse was performed. The alternative explanation, that the decline in transmission of HIV is a result of a so called saturation effect, is unlikely given that $60 \%$ of the participants were still not infected.

Data from the United States show higher percentages of infected men in three comparable cohorts. In a cohort of homosexual men from New York city $6.6 \%$ were infected with $\mathrm{HIV}$ in 1978-9, and the proportion had risen to $43.7 \%$ in early $1984 .{ }^{11}$ In the San Francisco men's health study a prevalence of HIV of $48.6 \%$ was found among the homosexual and bisexual members of a probability sample of single men in 1984. ${ }^{2}$ In the San Francisco city clinic cohort study the prevalence of HIV among a cohort selected from those attending sexually transmitted diseases clinics rose from $4.5 \%$ in 1978 to $73.1 \%$ in $1985 . .^{13}$ In 1980 more than $20 \%$ of the subjects in this last study were infected with HIV. At that time AIDS had not been diagnosed in any patient in The Netherlands and HIV had been introduced only recently in the male homosexual community in Amsterdam. ${ }^{8}$ From 1984 
onwards preventive activities were undertaken among homosexual men in The Netherlands to try to avoid the spread of AIDS such as that seen in the United States. There is little doubt that this influenced the sexual behaviour of homosexual men, which in turn reduced the transmission of HIV.

Additional evidence for this line of reasoning exists in the decrease in the number of men with acute hepatitis B and early syphilis. In 1984-7 these numbers decreased from 23 to 8 and from 92 to $31 / 100000$ men. Contact tracing showed that in many of these cases the diseases were acquired homosexually. These facts show that the sexual behaviour of homosexual men in Amsterdam started to change early in the epidemic in comparison with that in big cities in the United States. ${ }^{1+15}$ A considerable percentage of homosexual men in the United States had already been infected with HIV by the time the AIDS epidemic was recognised and sexual behaviour could be changed. The differences in prevalence of HIV infection between the Amsterdam cohort and the San Francisco city clinic cohort show that early preventive activities may have a huge impact on the transmission of HIV. Amsterdam, as well as some large cities in the United States and Europe, has a strong homosexual community, in which preventive activities specifically directed at homosexual men can be carried out, often by homosexual organisations with the aid of private and government funding.

As a result of the earlier interventions in Europe a smaller proportion of homosexual men in this continent has become infected with HIV than in the United States. Additional evidence for this hypothesis is found in a study among homosexual men in London, in which the prevalence of HIV antibody remained fairly stable at about $25 \%$ in 1986 after a rise from $3 \cdot 7 \%$ in 1982 to $18 \cdot 1 \%$ in $1985 .{ }^{16}$ Probably in the near future homosexual men will constitute a relatively smaller proportion of the total number of patients with AIDS in Europe than in the United States. This in turn has consequences for interpreting the relative growth and decline of other groups at risk of HIV infection in the Western world. Finally, we conclude that early preventive activities can be effective and that, at least in Amsterdam, they have considerably restricted the number of cases of AIDS among homosexual men.

This study was supported by grants 28-1127 and 28-1026 from The Netherlands Foundation for Preventive Medicine. We thank the participants in this study; F De Wolf, J Van Der Noordaa, R Tielman, N Albrecht-Van Lent, R Lopes Diaz, K Nittel, T Rijsdijk, C Hooykaas, J Houweling, C Kuiken, J Lange, and I Brus for their help.

1 Prummel MF, Ten Berge RJM, Barrowclough H, Cejka V. Kaposisarcoom en dodelijke opportunistische infekties bij een homoseksuele man met een deficient immuunapparaat. Ned Tijdschr Geneeskd 1983;127:820-4.

2 Anonymous. Aids surveillance in Europe. Paris: WHO Collaborating Centre, 1987. Quarterly report No 16;31 December 1987.

3 Van Griensven GJP, Tielman RAP, Goudsmit J, et al. Riskfactors and prevalence of HIV antibodies among homosexual men in The Netherlands. Am f Epidemiol 1987;125:1048-57.

4 Van Griensven GJP, De Vroome EMM, Tielman RAP, et al. Impact of HIV antibody testing on changes in sexual behavior among homosexual men in the Netherlands. Am f Public Health 1988;78:1575-7.

5 De Wolf $\mathrm{F}$, Lange JMA Goudsmit J, et al. Effect of zidovudine on serum human immunodeficiency virus antigen levels in symptom free subjects. Lancet 1988;i:373-6.

6 Lange JMA, Coutinho RA, Krone WJA, et al. Distinct IgG recognition patterns during progression of subclinical and clinical infection with lymphadenopathy associated virus/human T lymphotropic virus. $\mathrm{Br}$.Med $\mathcal{f}$ 1986:292:228-30

7 Coutinho RA, Lelie N, Albrecht-Van Lent P, et al. Efficacy of a heat inactivated hepatitis $B$ vaccine in male homosexuals; outcome of a placebo controlled double blind trail. Br Med f 1983;286:1305-8.

8 Coutinho RA, Krone WJA, Smit L, et al. Introduction of lymphadenopathy associated virus or human T lymphotropic virus (LAV/HTLV III) into the male homosexual community in Amsterdam. Genitourin Med 1986;62 $38-43$

9 Schwartz D, Flamant R, Lellouch J. Clinical trials. New York: Academic Press, 1980.

10 Draper NR, Smith H. Applied regression analysis. New York: Wiley, 1981

11 Stevens CE, Taylor PE, Zang EA, et al. Human T-cell lymphotropic virus typ III infection in a cohort of homosexual men from New York City. FAMA $1986 ; 225: 2167-72$.

12 Winkelstein W, Samuel M, Padian NS, et al. The San Francisco men's health study. III reduction in human immunodeficiency virus transmission amon homosexual/hisexual men, 1982-1986. Am. F Public Health 1987;77:685-9.

13 Centers for Disease Control. Acquired immunodeficiency syndrome in the San Francisco cohort study, 1978-85. M.MWR 1985;34:573-5.

14 McKusick L, Horstman W, Coates TJ. AIDS and sexual behavior reported by gay men in San Francisco. Am f Public Health 1985;75:493-6.

15 Centers for Disease Control. Self reported changes in sexual behaviors among homosexual and bisexual men from the San Franciseo city clinic cohort. MMWR 1987;36:187-9.

16 Carne CA, Johnson AM, Pearce F, et al. Prevalence of antibodies to human immunodeficiency virus, gonorrhoea rates and changed sexual behaviour in homosexual men in London. Lancet 1987;i:656-8.

Accepted 17 Norember 1988

\title{
Problems of diabetics in prison
}

\author{
G V Gill, I A MacFarlane
}

\begin{abstract}
Providing care for diabetics is difficult in prison. Six diabetic prisoners or former prisoners were seen whose care was difficult or unsatisfactory. Three had multiple admissions to hospital during their sentences with diabetic ketoacidosis that they induced themselves by not taking insulin. The motive seemed to be removal from prison to the fairly pleasant surroundings of the local hospital. A fourth prisoner required admission in a hyperglycaemic, hyperosmolar state that had gone unnoticed as he was thought to be "acting up." The two others had imperfect long term management of diabetes during their sentences.

There is clearly room for improvement in diabetic services in British prisons, but manipulative behaviour on the part of some diabetic prisoners may remain a problem.
\end{abstract}

I A MacFarlane, $\mathrm{MD}$ consultant physician

Correspondence to: Dr Gill.

Br.Hed 7 1989:298:221-3

\section{Introduction}

Recent reports have expressed concern over in adequacies in the present system of health care in
British prisons. ${ }^{1.3}$ The problems are complex and emotive, and audits of prison health care by outside bodies are rare. In this report we draw attention to difficulties in managing diabetes in a prison environment and give case reports from our diabetic clinics, located near one of Britain's largest prisons.

\section{Case reports}

SELF INDUCED KETOACIDOSIS (CASES 1-3)

A 44 year old man with insulin dependent diabetes of 13 years' duration (case 1) was serving a five year sentence. He was admitted to the local hospital six times with ketoacidosis. He was later found to have avoided taking insulin by squirting it into his clothes during supervised injections. He was also in contact with two other imprisoned men with type I diabetes (cases 2 and 3) and taught them this method of inducing ketosis, leading to a minor epidemic that caused severe disruption to both prison and hospital staff. One of these men (case 2) was admitted to hospital three times and the other twice with ketoacidosis induced by protest refusals of food and 